Check for updates

Cite this: RSC Adv., 2020, 10, 20882

Received 28th April 2020

Accepted 25th May 2020

DOI: $10.1039 / \mathrm{dOra03817b}$

rsc.li/rsc-advances

\section{Concentration-composition-isotherm for the ammonia absorption process of zirconium phosphate}

\author{
Masakuni Yamaguchi, ${ }^{a}$ Hiroki Miyaoka ${ }^{a b}$ and Yoshitugu Kojima (DD *ab
}

The ammonia absorption process of zirconium phosphate has been studied using the concentrationcomposition-isotherm (CCl), X-ray diffraction and thermogravimetry-mass spectrometry (TG-MS). It was clarified that the equilibrium plateau concentration appeared due to two phase coexistence.
The world is shifting toward a society that reaches zero $\mathrm{CO}_{2}$ emissions due to environmental issues. ${ }^{\mathbf{1 , 2}}$ Ammonia is a $\mathrm{CO}_{2}$ free fuel and easily liquefied by compression at $1 \mathrm{MPa}$ and 298 $\mathrm{K}$, and has a high gravimetric hydrogen density of $17.8 \mathrm{wt} \%$ and a highest volumetric hydrogen density that is above 1.5 times that of liquid hydrogen. ${ }^{3}$ Ammonia is also a burnable substance. Therefore, ammonia has advantages as a hydrogen and energy carrier for renewable energy. Unfortunately, ammonia is a deleterious substance. As the demand for ammonia increases, it is necessary to ensure safety. A large amount of water is used as an ammonia absorbent when leakage of ammonia occurs by accidents because of large solubility in water. ${ }^{\mathbf{4} 6}$ However, ammonia water has the higher ammonia equilibrium vapour concentration. ${ }^{7}$ Many solid-state ammonia storage materials such as metal halides, complex hydrides, proto-based materials and porous materials have been studied to decrease the vapour concentration of ammonia. ${ }^{4}$

Recently we have focused on zirconium phosphate to suppress the release of ammonia vapour concentration because of stable in air and water. The large ammonia absorption capacity 10.2 wt\% and low ammonia vapour concentration below 2 ppm have been reported. ${ }^{4}$ The low vapour concentration follows from acid-base reaction. X-ray diffraction indicated that zirconium phosphate undergoes a structural change by ammonia absorption. ${ }^{\mathbf{8} 9}$ The large capacity of zirconium phosphate will be based on the structural phase transition by ammonia absorption. In general, ammonia pressurecomposition-isotherm (PCI) has been used to characterize the phase transition behaviour by ammonia absorption. ${ }^{4}$ However, this phase transition cannot be observed by ammonia PCI measurement for zirconium phosphate because the practical

${ }^{a}$ Graduate School of Advanced Sciences of Matter, Hiroshima University, 1-3-1, Kagamiyama, Higashi-Hiroshima, Hiroshima 739-8530, Japan. E-mail: kojimay@ hiroshima-u.ac.jp

${ }^{b}$ Natural Science Center for Basic Research and Development, Hiroshima University, 13-1, Kagamiyama, Higashi-Hiroshima, Hiroshima 739-8530, Japan lower detection limit of the measuring system is $1 \mathrm{~Pa}(10 \mathrm{ppm}) .{ }^{\mathbf{1 0}}$ The ammonia vapour concentration and the ammonia concentration in the water solution have similar values. ${ }^{4}$

In this study, ammonia absorption process of zirconium phosphate was investigated by using ammonia concentrationcomposition-isotherm (CCI), X-ray diffraction (XRD) and thermogravimetry-mass spectrometry (TG-MS).

We used zirconium phosphate (ZrP) with layer structure $(\alpha$ zirconium phosphate, CZP-100 manufactured by Daiichi Kigenso Kagaku Kogyo Co., Ltd., Japan). Montmorillonite also has a layer structure. Unfortunately, the silicate layers of montmorillonite are dispersed in water and wasn't used as a reference. Therefore, insoluble proton-exchanged zeolite (HSZ-331HSA, silica/alumina ratio: $6 \mathrm{~mol} \mathrm{~mol}^{-1}$, specific surface area: $600 \mathrm{~m}^{2} \mathrm{~g}^{-1}$, particle size: $2-3 \mu \mathrm{m}$, manufactured by TOSOH Co., Ltd., Japan) was used as a reference. Those samples were used as received without further purification. The proton exchange capacities for $\mathrm{ZrP}$ and the zeolite are $6.6 \mathrm{mmol} \mathrm{g}^{-1}$ and $2.0 \mathrm{mmol} \mathrm{g}^{-1}$, respectively. The dilute ammonia water [200 $(0.02 \mathrm{wt} \%)$ to $3000 \mathrm{ppm}(0.3 \mathrm{wt} \%)]$ was prepared using the $10 \mathrm{wt} \%$ solution supplied from KENEI Pharmaceutical Co., Ltd. with ion-exchanged water.

The following experiment was performed to evaluate the ammonia storage capacity. ZrP was added to the ammonia water having various concentrations at about $298 \mathrm{~K}$. The $\mathrm{NH}_{3}$ concentration and the potential of hydrogen $(\mathrm{pH})$ were measured using ammonia meter (Orion Star A324 and Orion 9512 manufactured by Thermo Scientific Orion) and $\mathrm{pH}$ meter (CyberScan pH310 manufactured by EUTECH Ins.). Lower detection limit of the ammonia meter is $0.01 \mathrm{ppm}$.

Here, ammonia has two kinds of forms which are $\mathrm{NH}_{3}$ and $\mathrm{NH}_{4}{ }^{+}$in ammonia water. $\mathrm{NH}_{3}$ concentration $\left(\left[\mathrm{NH}_{3}\right]\right)$ was measured by the ammonia meter. Then, $\mathrm{NH}_{4}{ }^{+}$concentration $\left(\left[\mathrm{NH}_{4}{ }^{+}\right]\right)$was calculated using the following equation: ${ }^{11}$

$$
\left[\mathrm{NH}_{4}^{+}\right]=\frac{K_{b}}{10 \mathrm{pH}-14}\left[\mathrm{NH}_{3}\right]
$$


where $K_{\mathrm{b}}$ is the base dissociation constant $\left(K_{\mathrm{b}}=1.8 \times 10^{-5} \mathrm{M}\right.$, at $298 \mathrm{~K})^{\mathbf{1 2}}$ and $\mathrm{pH}$ is the potential of hydrogen. Then, we calculated the ammonia storage capacity $\left(C_{\mathrm{st}}\right)$ as

$$
C_{\mathrm{st}}=\left(\left[\mathrm{NH}_{3}\right]_{\mathrm{af}}+\left[\mathrm{NH}_{4}{ }^{+}\right]_{\mathrm{af}}-\left[\mathrm{NH}_{3}\right]_{\mathrm{be}}+\left[\mathrm{NH}_{4}{ }^{+}\right]_{\mathrm{be}}\right) \times L
$$

where $\left[\mathrm{NH}_{3}\right]_{\text {be }}$ and $\left[\mathrm{NH}_{3}\right]_{\text {af }}$ are $\mathrm{NH}_{3}$ concentration before and after $\mathrm{ZrP}$ is added, $\left[\mathrm{NH}_{4}{ }^{+}\right]_{\text {be }}$ and $\left[\mathrm{NH}_{4}{ }^{+}\right]_{\text {af }}$ are $\mathrm{NH}_{4}{ }^{+}$concentration before and after $\mathrm{ZrP}$ is added and $L$ is the volume of ammonia water.

Fig. 1(a) shows the ammonia CCI of ZrP. The ammonia equilibrium concentration is lower than $0.01 \mathrm{ppm}$ below the ammonia storage capacity about $3 \mathrm{mmol} \mathrm{g}^{-1}\left(1 \mathrm{~mol} \mathrm{NH}_{3}\right.$ per mol ZrP).

ZrP has the ammonia equilibrium plateau concentration of ca. $1 \mathrm{ppm}$ in the range from $4-6 \mathrm{mmol} \mathrm{g}^{-1}$ (1 to $2 \mathrm{~mol} \mathrm{NH}_{3}$ per mol ZrP), so we found that two phases coexist in this plateau region. The increase in the equilibrium concentration of ammonia from 3-4 $\mathrm{mmol} \mathrm{g}^{-1}$ will be based on the appearance of $\mathrm{Zr}\left(\mathrm{NH}_{4} \mathrm{PO}_{4}\right)_{2} \cdot \mathrm{H}_{2} \mathrm{O}$ phase. Subsequently, the ammonia equilibrium concentration drastically increases when $\mathrm{ZrP}$ is absorbed ammonia above $6 \mathrm{mmol} \mathrm{g}^{-1}\left(2 \mathrm{~mol} \mathrm{NH}_{3}\right.$ per mol ZrP). This capacity corresponds to the proton exchange capacity of $\mathrm{ZrP}$ $\left(6.6 \mathrm{mmol} \mathrm{g}^{-1}\right)$. It is suggested that ammonia is bonded to the proton site of $\mathrm{ZrP}$ and form ammonium ion below $6 \mathrm{mmol} \mathrm{g}^{-1}$ ( $2 \mathrm{~mol} \mathrm{NH}_{3}$ per mol $\mathrm{ZrP}$ ). Ammonia equilibrium concentration increases above $6 \mathrm{mmol} \mathrm{g}^{-1}$, since the proton site is absent.

According to ammonia CCI, we can interpret that two kinds of ammonia absorption sites exist in zirconium phosphate, which is shown in the formula,

$$
\begin{gathered}
\mathrm{Zr}\left(\mathrm{HPO}_{4}\right)_{2} \cdot \mathrm{H}_{2} \mathrm{O}+\mathrm{NH}_{3} \rightleftharpoons \mathrm{Zr}\left(\mathrm{NH}_{4} \mathrm{PO}_{4}\right)\left(\mathrm{HPO}_{4}\right) \cdot \mathrm{H}_{2} \mathrm{O} \\
\mathrm{Zr}\left(\mathrm{NH}_{4} \mathrm{PO}_{4}\right)\left(\mathrm{HPO}_{4}\right) \cdot \mathrm{H}_{2} \mathrm{O}+\mathrm{NH}_{3} \rightleftharpoons \mathrm{Zr}\left(\mathrm{NH}_{4} \mathrm{PO}_{4}\right)_{2} \cdot \mathrm{H}_{2} \mathrm{O}
\end{gathered}
$$

Fig. 1(b) shows ammonia CCI of the zeolite as a reference. Ammonia equilibrium concentration is lower than $0.01 \mathrm{ppm}$ below the ammonia storage capacity of $0.7 \mathrm{mmol} \mathrm{g}^{-1}$. The ammonia concentration increases with the storage capacity above this value. When ammonia is adsorbed up to the proton exchange capacity $\left(2 \mathrm{mmol} \mathrm{g}^{-1}\right)$, the ammonia concentration becomes about $500 \mathrm{ppm}$. The plateau concentration is not observed for the zeolite. This may be due to the fact that the

(a) Ammonia storage capacity/ (b)

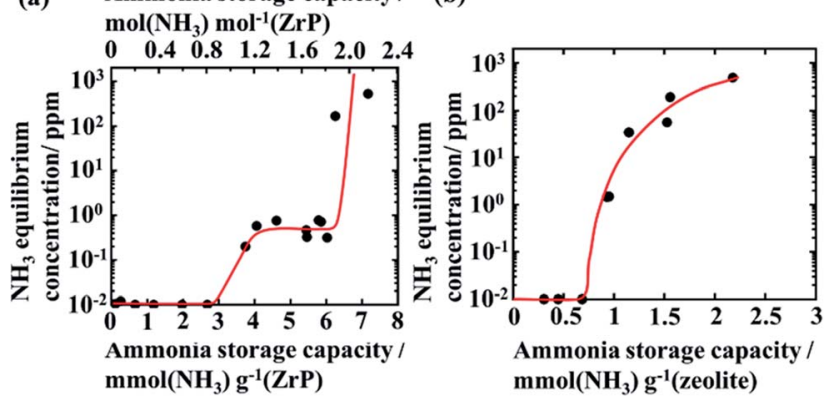

Fig. 1 Ammonia $\mathrm{CCl}$ in water at about $298 \mathrm{~K}$. (a) ZrP, (b) protonexchanged zeolite. zeolite has a porous structure and structural phase change does not occur by ammonia adsorption. Ammonia can be absorbed in $\mathrm{ZrP}$ by the structure change, because $\mathrm{ZrP}$ has interlayer spacing and interlayer proton for ammonia movement and the reaction.

It has been reported that the $\mathrm{Zr}\left(\mathrm{HPO}_{4}\right)_{2} \cdot \mathrm{H}_{2} \mathrm{O}$ and $\mathrm{Zr}\left(\mathrm{NH}_{4}-\right.$ $\left.\mathrm{PO}_{4}\right)_{2} \cdot \mathrm{H}_{2} \mathrm{O}$ has two-dimensional crystals. ${ }^{8,9} \mathrm{Zr}\left(\mathrm{HPO}_{4}\right)_{2} \cdot \mathrm{H}_{2} \mathrm{O}$ and $\mathrm{Zr}\left(\mathrm{NH}_{4} \mathrm{PO}_{4}\right)_{2} \cdot \mathrm{H}_{2} \mathrm{O}$ have the interlayer distance of $0.76 \mathrm{~nm}{ }^{8}$ and $0.96 \mathrm{~nm},{ }^{9}$ respectively.

XRD measurement was made in order to characterize the structures of the ZrP before and after ammonia absorption. XRD patterns were recorded on a Bragg-Brentano diffractometer (Rigaku RINT-2500V manufactured by Rigaku Co.) and $\mathrm{CuK} \alpha$ at tube current of $200 \mathrm{~mA}$ and tube potential of $40 \mathrm{kV}$. All samples were evacuated at room temperature for 20 hours to remove water from the surface of ZrP before XRD measurements. Each sample was pressed at a constant load on a glass holder before XRD measurement.

Fig. 2(a-c) show XRD patterns of $\mathrm{ZrP}, \mathrm{ZrP}$ absorbed ammonia, $\mathrm{Zr}\left(\mathrm{HPO}_{4}\right)_{2} \cdot \mathrm{H}_{2} \mathrm{O}$ (JCPDS 00-019-1489) and $\mathrm{Zr}\left(\mathrm{NH}_{4} \mathrm{PO}_{4}\right)_{2} \cdot \mathrm{H}_{2} \mathrm{O}$
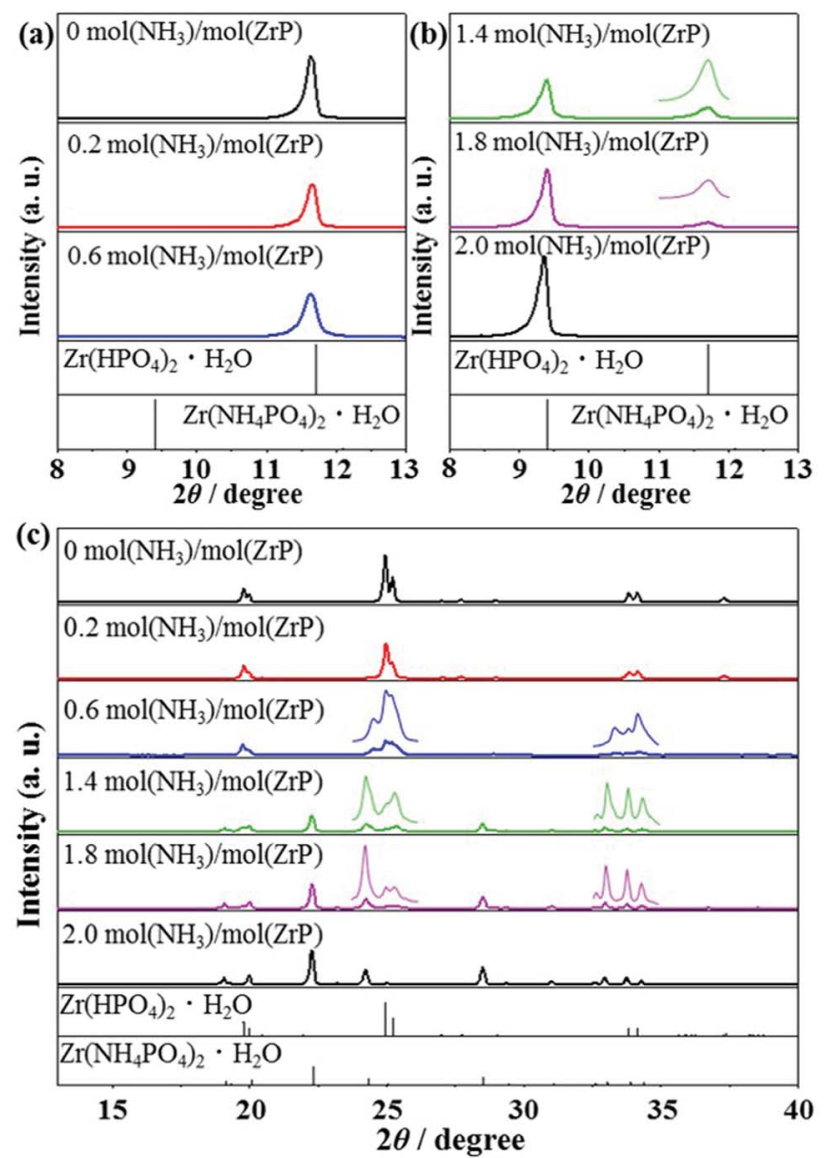

Fig. 2 XRD patterns of $\mathrm{ZrP}, \mathrm{ZrP}$ absorbed ammonia, $\mathrm{Zr}\left(\mathrm{HPO}_{4}\right)_{2} \cdot \mathrm{H}_{2} \mathrm{O}$ (JCPDS 00-019-1489) and $\mathrm{Zr}\left(\mathrm{NH}_{4} \mathrm{PO}_{4}\right)_{2} \cdot \mathrm{H}_{2} \mathrm{O}$ (JCPDS01-071-1633), (a) small angle $X R D$ patterns at $2 \theta$ of $8-13^{\circ}$ (ammonia storage capacity: $0.2,0.6 \mathrm{~mol} \mathrm{NH}_{3}$ per mol ZrP), (b) small angle XRD patterns at $2 \theta$ of $8-$ $13^{\circ}$ (ammonia storage capacity: 1.4, 1.8 and $2.0 \mathrm{~mol} \mathrm{NH}_{3}$ per mol ZrP), (c) wide angle $\mathrm{XRD}$ patterns at $2 \theta$ of $13-40^{\circ}$ (ammonia storage capacity: 0-2.0 $\mathrm{mol} \mathrm{NH}_{3}$ per mol ZrP). 
(JCPDS 01-071-1633) of the International Center for Diffraction Data (ICDD). Two peaks are observed for ZrP absorbed ammonia at 1.4 and $1.8 \mathrm{~mol} \mathrm{NH}_{3}$ per mol ZrP as shown in Fig. 2(b). The peak around $2 \theta$ of $9.4^{\circ}$ is the same as (002) diffraction of $\mathrm{Zr}\left(\mathrm{NH}_{4}{ }^{-}\right.$ $\left.\mathrm{PO}_{4}\right)_{2} \cdot \mathrm{H}_{2} \mathrm{O}$ having an interlayer distance of $0.96 \mathrm{~nm}$. Bragg peaks of the $\mathrm{ZrP}$ absorbed ammonia (1.4, 1.8 and $2.0 \mathrm{~mol} \mathrm{NH}_{3}$ per mol $\mathrm{ZrP})$ scattered to wide angle at $2 \theta$ of $13-40^{\circ}$ include all diffraction peaks of $\mathrm{Zr}\left(\mathrm{NH}_{4} \mathrm{PO}_{4}\right)_{2} \cdot \mathrm{H}_{2} \mathrm{O}$ (see Fig. 2(c)). We confirmed the presence of $\mathrm{Zr}\left(\mathrm{NH}_{4} \mathrm{PO}_{4}\right)_{2} \cdot \mathrm{H}_{2} \mathrm{O}$ in the $\mathrm{ZrP}$ absorbed ammonia. The interplanar spacing calculated by the broad peaks around $2 \theta$ of $11.6^{\circ}$ at 1.4 and $1.8 \mathrm{~mol} \mathrm{NH}_{3}$ per mol $\mathrm{ZrP}$ is similar to the interlayer distance $0.76 \mathrm{~nm}$ of $\mathrm{ZrP}$ in Fig. 2(a). However, according to Fig. 1(a) in the range from $4-6 \mathrm{mmol} \mathrm{g}^{-1}$ (1 to $2 \mathrm{~mol} \mathrm{NH}_{3}$ per mol $\mathrm{ZrP}$ ) and eqn (4), the broad peak around $2 \theta$ of $11.6^{\circ}$ can be explained by the presence of $\mathrm{Zr}\left(\mathrm{NH}_{4} \mathrm{PO}_{4}\right)\left(\mathrm{HPO}_{4}\right) \cdot \mathrm{H}_{2} \mathrm{O}$ having smaller crystallites and defects. ${ }^{13}$ The wide angle XRD patterns of the $\mathrm{ZrP}$ absorbed ammonia (1.4 $\mathrm{mol} \mathrm{NH}_{3}$ per mol $\mathrm{ZrP}$ ) show new shoulder at $2 \theta$ of $24.5^{\circ}$ which are absent in $\mathrm{ZrP}$ and $\mathrm{Zr}\left(\mathrm{NH}_{4}{ }^{-}\right.$ $\left.\mathrm{PO}_{4}\right)_{2} \cdot \mathrm{H}_{2} \mathrm{O}$ (Fig. 2(c)). This new shoulder may come from the structure of $\mathrm{Zr}\left(\mathrm{NH}_{4} \mathrm{PO}_{4}\right)\left(\mathrm{HPO}_{4}\right) \cdot \mathrm{H}_{2} \mathrm{O}$. One possible explanation is that two phases observed by ammonia CCI are $\mathrm{Zr}\left(\mathrm{NH}_{4} \mathrm{PO}_{4}\right)(-$ $\left.\mathrm{HPO}_{4}\right) \cdot \mathrm{H}_{2} \mathrm{O}$ and $\mathrm{Zr}\left(\mathrm{NH}_{4} \mathrm{PO}_{4}\right)_{2} \cdot \mathrm{H}_{2} \mathrm{O}$ in the range from 1 to $2 \mathrm{~mol}$ $\mathrm{NH}_{3}$ per mol ZrP.

Fig. 2(a) shows the small angle XRD patterns of ZrP and ZrP absorbed ammonia at 0.2 and $0.6 \mathrm{~mol} \mathrm{NH}_{3}$ per mol ZrP. Only one peak is observed for $\mathrm{ZrP}$ absorbed ammonia. XRD patterns of $\mathrm{ZrP}$ and $\mathrm{ZrP}$ absorbed $\mathrm{NH}_{3}$ are similar except for the XRD peaks at $2 \theta$ of $24.5^{\circ}$ and $33.3^{\circ}$ of the ZrP absorbed ammonia (0.6 $\mathrm{mol} \mathrm{NH}_{3}$ per mol ZrP). The new peaks suggest the presence of $\mathrm{Zr}\left(\mathrm{NH}_{4} \mathrm{PO}_{4}\right)\left(\mathrm{HPO}_{4}\right) \cdot \mathrm{H}_{2} \mathrm{O}$. These results can be understood by the coexistence of $\mathrm{ZrP}$ and $\mathrm{Zr}\left(\mathrm{NH}_{4} \mathrm{PO}_{4}\right)\left(\mathrm{HPO}_{4}\right) \cdot \mathrm{H}_{2} \mathrm{O}$ in the range from 0 to $1 \mathrm{~mol} \mathrm{NH}_{3}$ per mol ZrP.

Schematic representation of the two crystal phases in the ammonia equilibrium plateau concentration is shown in Fig. 3. The ratio of these two phases will be changed depending on the ammonia storage capacity from 1 to $2 \mathrm{~mol} \mathrm{NH}_{3}$ per mol $\mathrm{ZrP}$.

TG-MS measurement was carried out in order to obtain the desorbed gas, desorption temperature, and the weight loss of ZrP absorbed ammonia. TG-MS spectra were recorded on a TG (Rigaku plus RS-8200 manufactured by Rigaku Co.) and MS (MQA200TS manufactured by Anelva Co.) in a flowing Ar gas (300 $\mathrm{cm}^{3} \mathrm{~min}^{-1}$ ) with a heating rate of $5 \mathrm{~K} \mathrm{~min}^{-1}$. All samples were evacuated at room temperature for 20 hours to remove water from the surface of ZrP before TG-MS measurements.

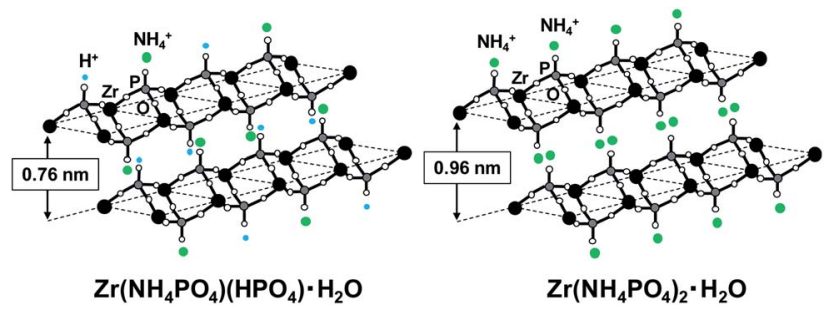

Fig. 3 Schematic representation of two-phase co-existence in zirconium phosphate absorbed ammonia $\left(\mathrm{NH}_{3} / \mathrm{ZrP}: 1-2 \mathrm{~mol} \mathrm{~mol}^{-1}\right)$.
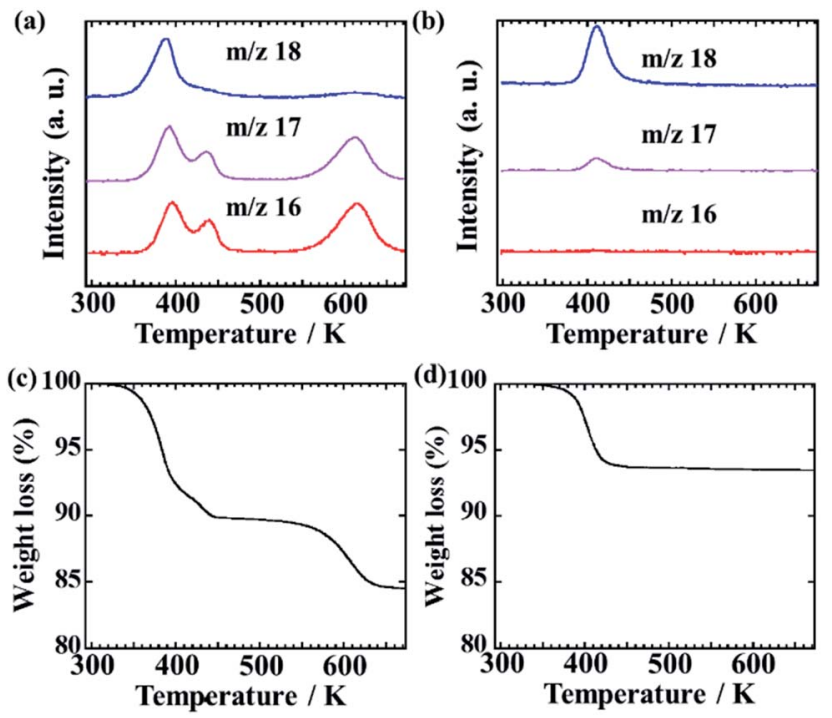

Fig. 4 MS spectra of (a) $\mathrm{Zr}\left(\mathrm{NH}_{4} \mathrm{PO}_{4}\right)_{2} \cdot \mathrm{H}_{2} \mathrm{O}$ and (b) $\mathrm{Zr}\left(\mathrm{HPO}_{4}\right)_{2} \cdot \mathrm{H}_{2} \mathrm{O}$. Blue, purple and red lines are $\mathrm{m} / z 18,17$ and 16 curves. TG spectra of (c) $\mathrm{Zr}\left(\mathrm{NH}_{4} \mathrm{PO}_{4}\right)_{2} \cdot \mathrm{H}_{2} \mathrm{O}$ and (d) $\mathrm{Zr}\left(\mathrm{HPO}_{4}\right)_{2} \cdot \mathrm{H}_{2} \mathrm{O}$.

Fig. 4(a) and (b) show the temperature dependences of mass spectra with $m / z \quad 16$ and 18 for $\mathrm{Zr}\left(\mathrm{NH}_{4} \mathrm{PO}_{4}\right)_{2} \cdot \mathrm{H}_{2} \mathrm{O}$ and $\mathrm{Zr}\left(\mathrm{HPO}_{4}\right)_{2} \cdot \mathrm{H}_{2} \mathrm{O}$. Here, the signal of $\mathrm{m} / z 18$ indicates a mainly water $\left(\mathrm{H}_{2} \mathrm{O}\right)$ and the signal of $\mathrm{m} / \mathrm{z} 16$ indicates an ammonia $\left(\mathrm{NH}_{2}{ }^{+}\right)$. It is noted that $m / z 16$ is defined as ammonia rather than $\mathrm{m} / z 17$ due to the water fragment ion effect on $\mathrm{m} / \mathrm{z} 17$. The peaks of $m / z 16$ for $\mathrm{Zr}\left(\mathrm{NH}_{4} \mathrm{PO}_{4}\right)_{2} \cdot \mathrm{H}_{2} \mathrm{O}$ are observed around 390 $\mathrm{K}, 440 \mathrm{~K}$ and $610 \mathrm{~K}$. It is indicated that $\mathrm{Zr}\left(\mathrm{NH}_{4} \mathrm{PO}_{4}\right)_{2} \cdot \mathrm{H}_{2} \mathrm{O}$ desorbs ammonia around these temperatures. Then, the peak area of ammonia based on $\mathrm{m} / \mathrm{z} 16$ from 350 to $460 \mathrm{~K}$ is the same as the peak area of ammonia from 550 to $650 \mathrm{~K}$. The peak area corresponds to the amount of ammonia desorption. Thus, $\mathrm{Zr}\left(\mathrm{NH}_{4} \mathrm{PO}_{4}\right)_{2} \cdot \mathrm{H}_{2} \mathrm{O}$ is suggested to release $1 \mathrm{~mol}$ of ammonia from 350 to $460 \mathrm{~K}$ and $1 \mathrm{~mol}$ of ammonia from 550 to $650 \mathrm{~K}$. The water desorption peaks of $m / z 18$ for $\mathrm{Zr}\left(\mathrm{NH}_{4} \mathrm{PO}_{4}\right)_{2} \cdot \mathrm{H}_{2} \mathrm{O}$ and $\mathrm{Zr}\left(\mathrm{HPO}_{4}\right)_{2} \cdot \mathrm{H}_{2} \mathrm{O}$ are observed around $390 \mathrm{~K}$ and $410 \mathrm{~K}$, respectively. The peak shift toward lower temperature of $\mathrm{Zr}\left(\mathrm{NH}_{4}\right.$ $\left.\mathrm{PO}_{4}\right)_{2} \cdot \mathrm{H}_{2} \mathrm{O}$ may be based on the interaction between water and ammonia.

Fig. 4(c) and (d) show the TG curves of $\mathrm{Zr}\left(\mathrm{NH}_{4} \mathrm{PO}_{4}\right)_{2} \cdot \mathrm{H}_{2} \mathrm{O}$ and $\mathrm{Zr}\left(\mathrm{HPO}_{4}\right)_{2} \cdot \mathrm{H}_{2} \mathrm{O}$. In Fig. 3(c), two main weight losses are observed in this process. The weight loss of $\mathrm{Zr}\left(\mathrm{NH}_{4} \mathrm{PO}_{4}\right)_{2} \cdot \mathrm{H}_{2} \mathrm{O}$ from 330 to $460 \mathrm{~K}$ is $10.5 \mathrm{wt} \%$ and the weight loss from 550 to $650 \mathrm{~K}$ is $5.1 \mathrm{wt} \%$. These weight losses come from the desorption of ammonia and water. In Fig. 3(d), the weight loss of $\mathrm{Zr}\left(\mathrm{HPO}_{4}\right)_{2} \cdot \mathrm{H}_{2} \mathrm{O}$ is $6.0 \mathrm{wt} \%$ from 330 to $460 \mathrm{~K}$. Thus, $\mathrm{Zr}\left(\mathrm{NH}_{4}{ }^{-}\right.$ $\left.\mathrm{PO}_{4}\right)_{2} \cdot \mathrm{H}_{2} \mathrm{O}$ desorbs $1 \mathrm{~mol}$ water and $1 \mathrm{~mol}$ ammonia from 330 to $460 \mathrm{~K}$, and desorbs $1 \mathrm{~mol}$ ammonia from 550 to $650 \mathrm{~K}$ by TG-MS measurement. Therefore, two kinds of ammonia absorption sites can exist in $\mathrm{Zr}\left(\mathrm{NH}_{4} \mathrm{PO}_{4}\right)_{2} \cdot \mathrm{H}_{2} \mathrm{O}$, as shown in the formula,

$$
\begin{gathered}
\mathrm{Zr}\left(\mathrm{NH}_{4} \mathrm{PO}_{4}\right)_{2} \cdot \mathrm{H}_{2} \mathrm{O} \rightarrow \mathrm{Zr}\left(\mathrm{NH}_{4} \mathrm{PO}_{4}\right)\left(\mathrm{HPO}_{4}\right)+\mathrm{H}_{2} \mathrm{O}+\mathrm{NH}_{3} \\
\mathrm{Zr}\left(\mathrm{NH}_{4} \mathrm{PO}_{4}\right)\left(\mathrm{HPO}_{4}\right) \rightarrow \mathrm{Zr}\left(\mathrm{HPO}_{4}\right)_{2}+\mathrm{NH}_{3}
\end{gathered}
$$


We have demonstrated that the structural phase transition was observed using ammonia concentration-compositionisotherm (CCI) measurement for the first time. The structural phase transition was confirmed by the X-ray diffraction (XRD). In addition two kinds of ammonia absorption sites were observed by TG-MS. Therefore, CCI is a useful method for investigating structural phase transition as well as PCI.

\section{Conflicts of interest}

There are no conflicts to declare.

\section{Acknowledgements}

This work was partially supported by Council for Science, Technology and Innovation (CSTI), Cross-ministerial Strategic Innovation Promotion Program (SIP), "energy carrier" (funding agency: JST). The author is greatly indebted to Professor T. Ichikawa of Hiroshima University for his help and discussion.

\section{Notes and references}

1 IPCC, Climate Change 2013: The Physical Science Basis Intergovernmental Panel on Climate Change, 2013, https:// www.ipcc.ch/report/ar5/wg1/.
2 F. Birol, The Future of Hydrogen, Seizing today's opportuinities, report prepared by the IEA for the G20, 82-83, Japan, June 2019.

3 Y. Kojima, Int. J. Hydrogen Energy, 2019, 44, 18179.

4 Y. Kojima and M. Yamaguchi, Int. J. Hydrog. Energy, 2020, 45, 10233.

5 NIST Chemistry WebBook, SRD 69, Thermophysical Properties of Ammonia, http://webbook.nist.gov/cgi/fluid.cgi? $\mathrm{ID}=\mathrm{C} 7664417$ \&Action $=$ Page.

6 Chemical Engineering Handbook, rev. 6 Edition, The Society of Chemical Engineers, Maruzen Co., Ltd., Japan, 1999, p. 81. http://ebw.eng-book.com/pdfs/ 879040e33a05a0e5f1cb85580ef77ad1.pdf.

7 E. P. Perman, J. Chem. Soc., 1903, 83, 1168.

8 L. Sedlakova and V. Pekarek, J. Less-Common Met., 1966, 10, 130.

9 A. Clearfield and J. M. Troup, J. Phys. Chem., 1973, 77, 243.

10 H. Miyaoka, H. Miyaoka, T. Ichikawa, T. Ichikawa and Y. Kojima, Int. J. Hydrogen Energy, 2018, 43, 14486.

11 P. Atkins, T. Overton, J. Rourke, M. Weller and F. Armstrong, Shriver and Atkins' Inorganic chemistry, 5th revised edn, 2009.

12 W. M. Burke, J. Am. Chem. Soc., 1920, 42, 2500.

13 B. D. Cullity, Elements of X-ray Diffraction, Addison-Wesley Publishing Company, Inc., Reading, Massachusetts, USA, 2nd edn, 1977. 